\title{
Growth and digestive enzymes of silver catfish fed diets containing fruit residue
}

\author{
[Crescimento e enzimas digestivas de jundiás alimentados com dietas \\ contendo resíduos de frutas] \\ R. Lazzari ${ }^{1}$, J. Uczay ${ }^{2}$, J.K.S. Henriques ${ }^{3}$, E.G. Durigon ${ }^{4}$, \\ D.F. Kunz, N.C. Peixoto ${ }^{1}$, D. Fronza ${ }^{6}$ \\ ${ }^{1}$ Universidade Federal de Santa Maria (UFSM) - Palmeira das Missões, RS \\ ${ }^{2}$ Aluno de pós-graduação - Universidade do Estado de Santa Catarina - Lages, SC \\ ${ }^{3}$ Aluno de pós-graduação - Universidade do Oeste Paraná - Marechal Cândido Rondon, PR \\ ${ }^{4}$ Aluno de pós-graduação - Universidade do Estado de Santa Catarina - Chapecó, SC \\ ${ }^{5}$ Aluno de graduação - UFSM - Palmeira das Missões, RS \\ ${ }^{6}$ Colégio Politécnico - UFSM - Santa Maria, RS
}

\begin{abstract}
In fish farming, the use of alternative ingredients has been studied, so that alternative sources can be used to minimize feed costs. This study evaluated the incorporation of grape, orange, guava, and fig residues in diets for silver catfish and its effects on growth, digestive enzymes and body composition. A total of 180 fish (initial mean weight $=22.93 \pm 0.75 \mathrm{~g}$ ) were reared in a recirculation aquaculture system. There was no difference $(\mathrm{P}>0.05)$ in the parameters of growth, dry matter, mineral matter, plasma protein, cholesterol, triglycerides, lipase, and trypsin of fish. Glucose levels were higher in fish fed diets containing fig, orange, and grape residue $(\mathrm{P}<0.05)$. Lipase activity was higher in fish fed orange residue, compared to guava $(\mathrm{P}<0.05)$. Diets containing guava and fig provided more body protein in silver catfish. The fish fed with diet containing orange residue had a higher content of body lipids. It can be concluded that the tested fruit residues can be used in silver catfish feeding.
\end{abstract}

Keywords: By-products, nutrition, Rhamdia quelen

\section{RESUMO}

Na piscicultura, o uso de ingredientes alternativos vem sendo estudado, de modo que seja possível utilizar fontes alternativas para minimizar custos com a alimentação. Neste estudo, foi avaliada a incorporação de resíduos de uva, laranja, goiaba e figo em rações para jundiá e seus efeitos no crescimento, em enzimas digestivas e na composição corporal. Foram utilizados 180 peixes (peso médio inicial $=22,93 \pm 0,75 \mathrm{~g})$, criados em sistema de recirculação. Não houve diferença $(P>0,05)$ nos parâmetros de crescimento, matéria seca, matéria mineral, proteína plasmática, colesterol, triglicerídeos, lipase e tripsina dos peixes. Os níveis de glicose foram maiores nos peixes alimentados com dietas contendo figo, laranja e uva $(P<0,05)$. A atividade de lipase foi maior nos peixes alimentados com resíduo de laranja, comparado com o de goiaba $(P<0,05)$. As dietas contendo goiaba $e$ figo proporcionaram mais proteína corporal nos jundiás. Os jundiás alimentados com dieta contendo resíduo de laranja apresentaram maior teor de lipídeos corporal. Conclui-se que os resíduos de frutas testados podem ser usados na alimentação do jundiá.

Palavras-chave: subprodutos, nutrição, Rhamdia quelen

Recebido em 14 de outubro de 2017

Aceito em 9 de abril de 2018

E-mail: rlazzari@ufsm.br 


\section{INTRODUCTION}

Feeding represents a very high cost in fish farming, mainly due to the great nutritional requirement of the animals. Traditionally, the feed industries use animal flours derived from poultry, pork, bovine or fish slaughter residues, and also of vegetable origin, where soybean and corn are the main protein and energy ingredient respectively (Pezzato et al., 2009). Considering that the plant products used in these formulations are by-products of industries, this makes them economically costly ingredients. The ingredients employed are often scarce, which means that the search for more available and cheaper alternatives can be used in these diets (Lemos et al., 2011).

The food industry, after processing the fruits for the manufacture of its products, generates a significant amount of residues such as shells, bagasse, pulp and whole fruits. Because fruit production is significant in our country and the consumption of many fruits in the in natura form is not very expressive, because they are perishable products, some industries are investing in its processing, since besides adding value, it stimulates consumption.

Brazilian fish farming has been a highlight in recent years. Brazil, for its climate, species and market potential, could become the world's largest fish producer. The silver catfish is a fish native to southern Brazil, has an omnivorous feeding habit, but it has protein nutritional requirement of carnivorous fish. For the case of a catfish family of siluriformes, this species lacks spines in the fillet, which favors its acceptance by consumers. The cultivation of this species had increased.

Fruit residues appear as an economically viable option to employ in formulating fish feeds. Thus, the objective of this study was to evaluate the incorporation of grape, orange, guava and fig residues in diets for silver catfish on performance, body composition, enzymatic and biochemical parameters.

\section{MATERIAL AND METHODS}

The feeding study was conducted in a recirculating aquaculture system at Fish Farming Laboratory at the Federal University of Santa Maria (UFSM), Campus Palmeira das Missões, Rio Grande do Sul (RS), Brazil. One hundred and eighty fish (Rhamdia quelen) were used $(22.93 \pm 0.75 \mathrm{~g}, 13.82 \pm 0.12 \mathrm{~cm})$, obtained in commercial fish farming. The experimental protocol was approved by the Committee for the Ethics of Animal Use - UFSM (n. 024/2013).

Fish were randomly distributed in fifteen polypropylene tanks $(250 \mathrm{~L}), 12$ fish per tank, and acclimated to the laboratory conditions for two weeks. Water parameters were checked daily (temperature, total ammonia, nitrite and dissolved oxygen) and weekly (alkalinity, total hardness and $\mathrm{pH}$ ). The values obtained were: temperature - morning $\left(25.89 \pm 0.98^{\circ} \mathrm{C}\right)$ and afternoon $\left(26.94 \pm 0.90^{\circ} \mathrm{C}\right)$, dissolved oxygen $(5.89 \pm 0.33 \mathrm{mg} / \mathrm{L}), \mathrm{pH}(7.62 \pm 0.53)$, alkalinity $\left(64.00 \pm 8.57 \quad \mathrm{mg} \quad \mathrm{CaCO}_{3} / \mathrm{L}\right)$, darkness $\left(97.71 \pm 12.89 \mathrm{mg} \mathrm{CaCO}_{3} / \mathrm{L}\right)$, total ammonia $(2.18 \pm 0.74 \mathrm{mg} / \mathrm{L})$ e nitrite $(0.12 \pm 0.05 \mathrm{mg} / \mathrm{L})$.

The fruits residues were processed in Fish Farming Laboratory of UFSM, Campus Santa Maria, RS, Brazil. Orange residues were obtained after juice produced. Grape residues were obtained after vine produced. Fig and guava residues were obtained processed pulp. All fruits residues were dried in recirculate stove with $40^{\circ} \mathrm{C}$ for $72 \mathrm{~h}$. Diets were formulated based on the study of Lazzari et al. (2008). All ingredients were finely ground, weighed and mixed by kneading until homogeneous. After it was addition of fruits residues (Table 1). The water was then added to the diets, and a drying process was performed in a forced air circulation oven for $24 \mathrm{~h}\left(40^{\circ} \mathrm{C}\right)$. Finally, the pellets were broken, sieved and stored in a freezer until use. The fish received the experimental diets until apparent satiation twice a day ( 9 and $17 \mathrm{~h}$ ), for 45 days. The experimental design resulted in four treatments and three replicates. 
Table 1. Centesimal composition (\%) of the experimental diets

\begin{tabular}{ccccc} 
& \multicolumn{5}{c}{ Diet } \\
\cline { 2 - 5 } & Orange & Guava & Grape & Fig \\
\hline Meat and bone meal & 35 & 35 & 35 & 35 \\
Soybean meal & 32 & 32 & 32 & 32 \\
Orange & 10 & & & \\
Guava & & 10 & 10 & \\
Grape & & & & 12 \\
Fig & 8 & 8 & 8 & 6 \\
Corn & 9 & 9 & 9 & 9 \\
Rice meal & 1 & 1 & 1 & 1 \\
Soybean oil & 3 & 3 & 3 & 3 \\
Minerals and vitamins & 1 & 1 & 1 & 1 \\
Salt & 1 & 1 & 1 & \\
Dicalcium phosphate & & \multicolumn{2}{c}{ Composition } & \\
Dry matter & $95.91 \pm 0.09$ & $95.17 \pm 0.04$ & $95.60 \pm 0.09$ & $93.85 \pm 0.16$ \\
Ash & $14.07 \pm 0.22$ & $13.66 \pm 0.03$ & $13.27 \pm 0.17$ & $13.65 \pm 0.06$ \\
Crude protein & $38.82 \pm 1.31$ & $38.45 \pm 0.23$ & $38.26 \pm 0.03$ & $37.96 \pm 0.26$ \\
NDF* & $18.97 \pm 1.85$ & $22.92 \pm 1.25$ & $12.10 \pm 0.58$ & $22.48 \pm 0.94$ \\
Lipids & $11.95 \pm 0.82$ & $11.37 \pm 0.10$ & $11.56 \pm 0.56$ & $11.59 \pm 0.36$ \\
NNE** & 83.81 & 86.4 & 75.19 & 85.68 \\
Crude energy*** & 6794.745 & 6826.805 & 6368.715 & 6789.92 \\
\hline
\end{tabular}

Composition vitamins and minerals: Vitamin and mineral blend (assurance levels per $100 \mathrm{~g}$ of product) - folic acid 8 $\mathrm{mg}$; nicotinic acid $160 \mathrm{mg}$; pantothenic acid $80 \mathrm{mg}$; cobalt $0.06 \mathrm{mg}$; copper $20 \mathrm{mg}$; biotin $0.32 \mathrm{mg}$; iron $333 \mathrm{mg}$; iodine $0.66 \mathrm{mg}$; manganese $133 \mathrm{mg}$; selenium $0.66 \mathrm{mg}$; vitamin A $2.4 \mathrm{mg}$; vitamin D3 $0.03 \mathrm{mg}$; vitamin B1 $320 \mathrm{mg}$; vitamin B2 $320 \mathrm{mg}$; vitamin B6 $320 \mathrm{mg}$; vitamin B12 $32 \mu \mathrm{g}$; vitamin C $320 \mathrm{mg}$; vitamin K3 $16 \mathrm{mg}$; zinc 2 0mg. Vitamin E $120 \mathrm{mg}$

*NDF: Neutral Detergent Fiber

** NNE: Non-nitrogenous extraction: Determined by calculation: NNE $=100-(\mathrm{CP}+\mathrm{Ash}+\mathrm{lip}+\mathrm{NDF})$

$* * *$ Determined by calculation: Crude Energy $=[($ Crude Protein $\times 5.65)+($ Lipids x 9.4 $)+($ NNE x 4.15) $] \times 10$

The fish, in each tank, were individually weighed and measured on days 0 and 45 of experiment. However, the biomass of each tank was determined weekly to adjust the food supply. The blood sampling was performed from the caudal vein with heparinized sterile syringes. The fish were then euthanized by sectioning in spinal cord and the liver were removed and immediately frozen. The plasma was stored at $-80^{\circ} \mathrm{C}$ for further analysis. Total proteins, triglycerides, cholesterol and glucose levels in plasma were determined by using commercial kits (Labtest, Lagoa Santa/MG, Brazil).

Cholesterol: the sample was treated with esterase cholesterol $\geq 250 \mathrm{U} / \mathrm{L}$ for hydrolysis of cholesterol esters and with oxidase cholesterol $\geq$ $250 \mathrm{U} / \mathrm{L}$ for formation of hydrogen peroxide. The total cholesterol was determined by reaction of hydrogen peroxide with peroxidase enzyme $\geq$ $1,000 \mathrm{U} / \mathrm{L}$, phenol $24 \mathrm{mmol} / \mathrm{L}$ and 4aminoantipyrine $500 \mu \mathrm{mol} / \mathrm{L}$ in a medium buffered at $\mathrm{pH} 7.0$. The incubation, at $37^{\circ} \mathrm{C}$, was for $10 \mathrm{~min}$ and the formed red product was determined by spectrophotometry at $500 \mathrm{~nm}$. For calculations was used as reference a standard solution and the results are in $\mathrm{mg} / \mathrm{dL}$.

Glucose: the quantification was carried out by measuring the product formed in a reaction medium containing phosphate buffer $30 \mathrm{mmol} / \mathrm{L}$ $\mathrm{pH} 7.5$, phenol $\geq 1 \mathrm{mmol} / \mathrm{L}$, glucose oxidase $\geq$ $12,500 \mathrm{U} / \mathrm{L}$, peroxidase $\geq 800 \mathrm{U} / \mathrm{L}$ and 4 aminoantipyrine $\geq 290 \mu \mathrm{mol} / \mathrm{L}$. The incubation was started by adding $20 \mu \mathrm{L}$ of sample and realized at $37^{\circ} \mathrm{C}$ for $10 \mathrm{~min}$. The absorbances were measured at $505 \mathrm{~nm}$, the sample glucose concentration was compared to a glucose standard solution and expressed in $\mathrm{mg} / \mathrm{dL}$.

Proteins: the dosage was carried out in a reaction medium containing copper sulphate $12 \mathrm{mmol} / \mathrm{L}$ in sodium hydroxide $600 \mathrm{mmol} / \mathrm{L}$. The incubation was started by adding $50 \mu \mathrm{L}$ of 
sample and realized at $37^{\circ} \mathrm{C}$ for $10 \mathrm{~min}$. The absorbances were recorded at $545 \mathrm{~nm}$ and the sample total proteins concentration (in $\mathrm{g} / \mathrm{dL}$ ) was compared to a standard solution of bovine albumin.

Triglycerides: the level of these lipids (expressed in $\mathrm{mg} / \mathrm{dL}$ ) was determined, in a medium buffered at $\mathrm{pH} 7.0$ containing magnesium ions $4 \mathrm{mmol} / \mathrm{L}$, by addition of lipoprotein lipase $\geq 1.400 \mathrm{U} / \mathrm{L}$, glycerolkinase $\geq 1.000 \mathrm{U} / \mathrm{L}, \quad$ glycerol-3phosphate oxidase $\geq 1.500 \mathrm{U} / \mathrm{L}$ and ATP 1.8 $\mathrm{mmol} / \mathrm{L}$. Finally, 4-aminoantipyrine $300 \mu \mathrm{mol} / \mathrm{L}$, 4-chorophenol $2.70 \mathrm{mmol} / \mathrm{L}$ and peroxidase $\geq$ $900 \mathrm{U} / \mathrm{L}$ were added to oxygen peroxide formed. The reactions were conducted at $37^{\circ} \mathrm{C}$ for $10 \mathrm{~min}$ and the color intensity of formed product was determined at $505 \mathrm{~nm}$ and compared to standard solution.

The results are expressed as the means \pm standard deviation of the mean. The data were assessed for normality using a Shapiro-Wilk test.
The data showing normality were compared using a one-way analysis of variance (ANOVA) followed by Duncan's test. All analyses were performed with Statistical Analyses Software 11.0, and differences were considered significant at $\mathrm{P}<0.05$.

\section{RESULTS AND DISCUSSION}

The fish growth was not affected $(\mathrm{P}<0.05)$ by different fruit residue included in diets (Table 2), in all performance parameters evaluated [weight (W), total length (TL), standard length (SL), condition factor (CF), specific growth rate (SGR), digestive somatic index (DSI) and hepatosomatic index (HSI)]. Comparing CF and SRG values, it is noticed that the fish had no impairment of growth with the inclusion of fruit residue. In this study, SGR was approximately 1.06 to $1.37 \% /$ day. Juvenile of silver catfish fed only soybean meal as protein source had a SGR in the range of $0.8 \%$ /day and when fed with fish meal was 2.2\%/day (Lazzari et al., 2008).

Table 2. Growth parameters and body composition of silver catfish fed residues fruit

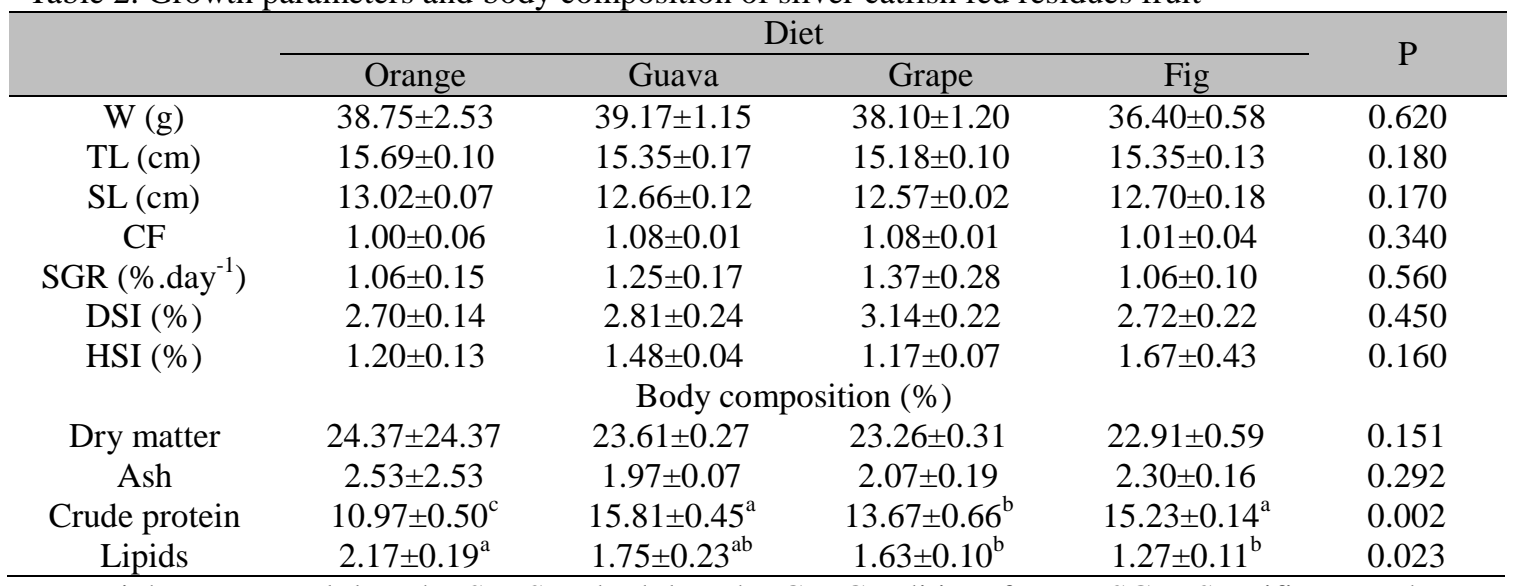

$\mathrm{W}=$ weight; $\mathrm{TL}=$ Total length; $\mathrm{SL}=$ Standard length; $\mathrm{CF}=$ Condition factor; $\mathrm{SGR}=$ Specific growth rate; DSI=digestive somatic index; HSI=Hepatosomatic index.

Different letters in the same row differ by Duncan's test $(\mathrm{P}<0.05)$.

The silver catfish has nutritional requirements of carnivore, but happily accepts diets of plant origin (Fracalossi et al., 2004), evidencing a great feature of this species in the utilization of plant sources. The use of agricultural by-products can be added to fish diets without altering their performance, either when these sources are substitutes for protein ingredients (Pedron et al., 2008; Bezerra et al., 2014; Santos et al., 2009) and energy (Souza et al., 2013; Lima et al. 2011, Santos et al., 2009).
In this study the same residue guava, with a $22.91 \%$ of NDF did not affect the performance of silver catfish, demonstrating the potential of this species in the use of fibrous materials. For Nile tilapia (Oreochromis niloticus) the use of fruit in diets improve weight gain, however this fish can more easily to convert vegetables sources (Lima, 2011). Similarly, Lemos et al. (2011) did not obtain good results including coconut meal for tambaqui (Colossoma macropomum). For this 
specie, the inclusion of mango flour (50\%, diet with $23 \% \mathrm{CP}$ ), having as main source the soybean meal in the diet, provide higher growth (Bezerra, et al., 2014).

The DSI (Table 2) showed no difference $(\mathrm{P}>0.05)$. This variable indicates the adaptation of the gastrointestinal tract to type of food ingested. As the composition of the ingredients, the digestive tract of fish may increase in size and weight (volume) in an attempt to increase the area of contact with the food and improving the digestibility (Leenhouwers et al., 2006). Silver catfish fed different levels of dietary fiber (7, 4 and $10 \%$ ) and two fiber sources (cottonseed and soybean hulls) did not affect the DSI, even after an experimental period of 120 days (Pedron et al., 2008).

The body lipid content was lower in the fish treated with fig and grape residue $(\mathrm{P}<0.05)$. The other parameters (dry matter and ash) had no difference between treatments. The crude protein was higher in the groups treated with fig and guava residue. The effect on the lipids centesimal composition suggests high content of phenolic compounds (Akbarian et al., 2015) in orange residue may be affect the digestibility of nutrients and increase the lipids. The fibers reduced lipids synthesis, but these antinutritional compounds block this mechanism. Lazzari et al. (2015) found no differences in the body composition of piava (Leporinus obtusidens) fed with the same fruit residues used in the present study.

The higher protein contents in fish feed with diet containing guava and fig may be related to feature of these diets, whose were made with the whole fruits, considering that the antinutritional compounds are concentrated in peel and husks peel and residue. Thus, in the protein content of these diets are included little of these portions.

Glucose levels (Table 3) were higher in fish fed with diets containing fig, orange and grape, but this did not differ from last guava. The determination of plasma glucose is important for the knowledge of the metabolism of fish compared to diet changes, besides serving as an indicator of health is related to stress conditions. Diets containing only plant sources provide higher levels of plasma glucose due to the increased amount of carbohydrates present in these ingredients (Kumar et al., 2010).

Table 3. Blood and enzymatic parameters of silver catfish fed fruit residues

\begin{tabular}{|c|c|c|c|c|c|}
\hline & \multicolumn{4}{|c|}{ Diet } & \multirow{2}{*}{$\mathrm{P}$} \\
\hline & Orange & Guava & Grape & Fig & \\
\hline Protein $(\mathrm{g} / \mathrm{dL})$ & $4.19 \pm 0.31$ & $4.33 \pm 0.42$ & $4.52 \pm 0.10$ & $4.63 \pm 0.49$ & 0.82 \\
\hline $\begin{array}{l}\text { Glucose } \\
\text { (mg/dL) }\end{array}$ & $90.72 \pm 10.29^{a}$ & $58.00 \pm 1.52^{\mathrm{b}}$ & $73.25 \pm 6.17^{\mathrm{ab}}$ & $99.00 \pm 14.22^{\mathrm{a}}$ & 0.05 \\
\hline $\begin{array}{c}\text { Cholesterol } \\
(\mathrm{mg} / \mathrm{dL})\end{array}$ & $99.83 \pm 8.28$ & $82.56 \pm 4.51$ & $83.15 \pm 3.27$ & $86.35 \pm 10.52$ & 0.26 \\
\hline $\begin{array}{l}\text { Triglycerides } \\
\text { (mg/dL) }\end{array}$ & $800.87 \pm 72.90$ & $884.73 \pm 74.75$ & $757.17 \pm 39.85$ & $788.72 \pm 85.63$ & 0.58 \\
\hline $\begin{array}{l}\text { Chymotrypsin } \\
(\mu \mathrm{mol} / \mathrm{L})\end{array}$ & $\begin{array}{c}22551.16 \pm 1020 \\
7\end{array}$ & $\begin{array}{c}27500.48 \pm 2061 \\
2\end{array}$ & $21579.69 \pm 1378$ & $\begin{array}{c}23252.54 \pm 1627 \\
1\end{array}$ & 0.09 \\
\hline $\begin{array}{c}\text { Trypsin } \\
(\mu \mathrm{mol} / \mathrm{L})\end{array}$ & $38.51 \pm 2.91$ & $40.65 \pm 3.64$ & $31.33 \pm 2.20$ & $39.60 \pm 1.85$ & 0.13 \\
\hline Lipase (U/L) & $23.44 \pm 0.86^{\mathrm{a}}$ & $18.35 \pm 1.40^{\mathrm{b}}$ & $20.24 \pm 0.55^{\mathrm{ab}}$ & $20.68 \pm 1.06^{\mathrm{ab}}$ & 0.03 \\
\hline
\end{tabular}

Different letters in the same row differ by Duncan's test $(\mathrm{P}<0.05)$.

High levels of plasma glucose can be harmful to the fish, leading to a reduction in food intake and hence growth (Baldisserotto, 2009). The significative decrease in blood glucose level and a lower cholesterol levels observed (around 20\% lower than that detected in fish fed with orange residue) in the group treated with guava may be due to high content of fiber of this fruit (Martínez et al., 2012) when compared to others, where the absorption of these nutrients is decreased.

In this study, there was no effect $(\mathrm{P}>0.05)$ of treatment in the case of plasma protein, 
cholesterol and triglycerides (Table 3). Elevated levels of plasma proteins can be indicate organ damage, which might be in diet intake. High levels of cholesterol and triglycerides may occur when there is a large increase in a condition of oxidative stress, which can also happen when there is a diet deficient in antioxidants (Gao et al., 2012). Moreover, the triglycerides content detected in blood of these fish (least at $10 \%$ higher than the other groups) suggests that the carbohydrate is converted in these lipids.

The cholesterol content verified in animals of the groups fed with grape (around 20\% lower than that detected in fish fed with orange residue) may be associated to presence of resveratrol, one natural phenol cited as a cardioprotective substance by reduce the levels of low density lipoproteins levels and, consequently, the total cholesterol (Zhang et al., 2015).

The lipase was also lower in fish fed with residue guava $(\mathrm{P}<0.05)$ when this is compared to the residue orange. There was no difference in lipase activity among catfish fed with residue guava, grape and fig ( $>0.05)$ (Table 3$)$.

Lipase activity was higher in diets containing residue of grape, orange and fig, but did not differ from guava. According to Moura et al. (2012), lipase is influenced more by water temperature, but can also increase when there is an increase in feed intake, because this higher concentration of substrate may have stimulated the pancreas to produce larger quantities lipase, increasing the efficiency of utilization of lipids.

The activity of chymotrypsin was higher in the diet with residue guava, not differing from residue fig and orange. The grapes had the lowest activity of chymotrypsin, but did not differ from the residue of fig and orange (Table 3 ). These differences may be related to the fact that alkaline proteases suffer from more changes related to diet composition than the level of protein (Lazzari et al., 2010). For juvenile grass carp (Ctenopharyngodon idella) the activity of alkaline proteases is lower when these are exclusively fed diet without the addition of forage (Costa et al., 2011). Carps have high potential to secrete proteases (Hidalgo et al., 1999), especially for digesting the proteins of the ingredients of plant origin, which have lower digestibility (Kuz'Mina, 1990).
The trypsin activity did not differ between treatments (Table 3). Second Ray (1988), the composition of the diet and feeding habits of each species influences the activity of digestive enzymes of fish, which may explain this result, for the grass carp, there is a correlation between the amount of food and secretion of digestive enzymes (Das and Tripathi, 1991). The piava juveniles showed higher trypsin in fish fed with bits containing fig and guava (Lazzari et al., 2015).

The increased trypsin activity in fish fed diets with high fiber content may show a way to compensate for the low quality and quantity of dietary protein consumed. In work conducted with the silver catfish (Rhamdia quelen) and pintado (Pseudoplatystoma corruscans) activity of alkaline proteases (trypsin and chymotrypsin) was found to suffer greater influence on the type of diet than by varying the amount of protein (Lundstedt et al., 2004). Regarding the activity of alkaline proteases, there are differences between the species, when are considered the distinct feed habits (Sinha et al., 2011).

Some studies show the importance of balance between carbohydrates, lipids and proteins as a protein sparing effect in the diet (Almeida, 2010). Others correlate the metabolic adaptation of each species to the food offered (Corrêa et al., 2007). Considering the growth parameters, together with biochemical, one realizes that no residue caused damage in the body of the silver catfish, which from an economic point of view is interesting, because the inclusion of these byproducts can reduce the cost of diet.

\section{CONCLUSION}

The residues of fig, orange, grape and guava can be used in diets for silver catfish without loss growth.

\section{ACKNOWLEDGMENTS}

The authors are grateful to the Conselho Nacional de Desenvolvimento Tecnológico (CNPq), for scientific initiation scholarship (PIBIC-UFSM 2012) and FAPERGS - RS (Process 11.1626-6, Ed. ARD/2011). 


\section{REFERENCES}

AKBARIAN, A.; GOLIAN A.; KERMANSHAHI, H. et al. Antioxidant enzyme activities, plasma hormone levels and serum metabolites of finishing broiler chickens reared under high ambient temperature and fed lemon and orange peel extracts and Curcuma xanthorrhiza essential oil. J. Anim. Physiol. Anim. Nutr., v.99, p.150$162,2015$.

ALMEIDA, L.C. Desempenho produtivo, eficiência digestiva e perfil metabólico de juvenis de tambaqui, Colossoma macropomum alimentados com diferentes taxas carboidrato/lipídio. 2010. 103f. Tese (Doutorado em Genética e Evolução) - Universidade Federal de São Carlos, São Carlos, SP.

BALDISSEROTTO, B. Fisiologia de peixes aplicada à piscicultura. 2.ed. Santa Maria: UFSM, 2009. 352p.

BEZERRA, S.K.; SOUZA, R.C.; MELO, J.F.B. et al. Crescimento de tambaqui alimentado com diferentes níveis de farinha de manga e proteína na ração. Arch. Zootec., v.44, p.587-598, 2014.

CORRÊA, C.F.; AGUIAR, L.H.; LUNDSTEDT, L.M. et al. Responses of digestive enzymes of tambaqui (Colossoma macropomum) to dietary cornstarch changes and metabolic inferences. Comp. Biochem. Physiol., v.147, p.857-862, 2007.

COSTA, M.L.; RADÜNZ NETO, J.; LAZZARI, R. et al. Enzimas digestivas de juvenis de carpa capim alimentados com forragem e ração. Arch. Zootec., v.60, p.563-570, 2011.

DAS, K.M.; TRIPATHI, S.D. Studies of digestive enzymes of grass carp (Ctenopharyngodon idella Val.). Aquaculture, v.92, p.21-32, 1991.

FRACALOSSI, D.M.; MEYER, G.; SANTAMARIA F.M. et al. Desempenho do jundiá, Rhamdia quelen, e do dourado, Salminus brasiliensis, em viveiros de terra na região sul do Brasil. Acta Sci. Anim., v.26, p.345-352, 2004.

GAO, J.; KOSHIO, S.; ISHIKAWA, M. et al. Effects of dietary oxidized fish oil with vitamin E supplementation on growth performance and reduction of lipid peroxidation in tissues and blood of red sea bream Pagrus major. Aquaculture, v.356-357, p.73-79, 2012.
HIDALGO, M.C.; UREA, E.; SANZ, A. Comparative study of digestive enzymes in fish with different nutritional habits. Proteolytic and amylase activities. Aquaculture, v.170, p.267283, 1999.

KUMAR, V.; HARINDER, P.S.; MAKKAR, A. Physiological, haematological and histopathological responses in common carp (Cyprinus carpio L.) fingerlings fed with differently detoxified Jatropha curcas kernel meal. Food. Chem. Toxicol., v.48, p.2063-2072, 2010 .

KUZ'MINA, V. Temperature influence on the total level of proteolytic activity in the digestive tract of some species of freshwater fishes. $J$. Ichthyol., v.30, p.97-109, 1990.

LAZZARI, R.; RADÜNZ NETO, J.; PEDRON F.A. et al. Desempenho e composição dos filés de jundiás (Rhamdia quelen) submetidos a diferentes dietas na fase de recria. Arq. Bras. Med. Vet. Zootec., v.60, p.477-484, 2008.

LAZZARI, R.; RADÜNZ NETO, J.; PEDRON, F.A. et al. Protein sources and digestive enzyme activities in jundiá (Rhamdia quelen). Sci. Agric., v.67, p.259-266, 2010.

LAZZARI, R.; UCZAY, J.; RODRIGUES, R.B. et al. Utilização de resíduos de frutas em dietas para piava. Bol. Inst. Pesca, v.40, p.227-237, 2015.

LEENHOUWERS, J.I.; ADJEI-BOATENG, D.; VERRETH, J.A.J. et al. Digesta viscosity, nutrient digestibility and organ weights in African catfish (Clarias gariepinus) fed diets supplemented with different levels of a soluble non-starch polysaccharide. Aquacul. Nutr., v.12, p.111-116, 2006.

LEMOS, M.V.A.; GUIMARÃES, I.G.; MIRANDA, E.C. Farelo de coco em dietas para o tambaqui (Colossoma macropomum). Rev. Bras. Saúde Prod. Anim., v.12, p.188-198, 2011.

LIMA, M.R.; LUDKE, M.C.M.M.; PORTO NETO, F.F. et al. Farelo de resíduo de manga para tilápia do Nilo. Acta Sci. Anim. Sci., v.33, p.65-71, 2011

LUNDSTEDT, L.M.; MELO, J.F.B.; MORAES, G. Digestive enzymes and metabolic profile of Pseudoplatystoma corruscans (Teleostei, Siluriformes) in response to diet composition. Comp. Biochem. Physiol. B, v.137, p.331-339, 2004. 
MARTÍNEZ, R.; TORRES, P.; MENESES, M.A. Technological and in vitro antioxidant properties of mango, guava, pineapple and passion fruit dietary fibre concentrate. Food Chem., v.135, p.1520-1526, 2012.

MOURA, G.S.; OLIVEIRA, M.G.A.; LANNA, E.A.T. Desempenho e atividade de lipase em tilápias do Nilo. Arch. Zootec., v.61, p.367-374, 2012.

PEDRON, F.A.; RADÜNZ NETO, J.; EMANUELLI, T. et al. Cultivo de jundiás alimentados com dietas com casca de soja ou de algodão. Pesqui. Agropecu. Bras., v.43, p.93-98, 2008.

PEZZATO, L.E.; BARROS, M.M.E.; FURUYMA, W.M. Valor nutritivo dos alimentos utilizados na formulação de rações para peixes tropicais. Rev. Bras. Zootec., v.38, p.43-51, 2009.

RAY, A.K. On the digestive enzymes in three Indian freshwater perches in relation to food and feeding habits. J. Inl. Fish. Soc. India, v.20, p.1$5,1988$.
SANTOS, E.L.; LUDKE, M.C.; BARBOSA, J.M. et al. Níveis de farelo de coco em rações para alevinos de tilápia do Nilo. Rev Bras Saúde Prod Anim., v.10, p.390-397, 2009.

SINHA, A.K.; KUMAR, V.; MAKKAR, H.P.S. et al. Non-starch polysaccharides and their role in fish nutrition. Food Chem., v.127, p.14091426, 2011.

SOUZA, R.C.; MELO, J.F.B.; NOGUEIRAFILHO, R.M. et al. Influência da farinha de manga no crescimento e composição corporal da tilápia do Nilo. Arch Zootec., n.62, p.217-225, 2013.

ZHANG, C.; LUO, J.; YU, B.; CHEN, J.; CHEN, D. Effects of resveratrol on lipid metabolism in muscle and adipose tissues: a reevaluation in a pig model. J. Func. Foods, v.14, p.590-595, 2015. 